\title{
Jual Beli Model 'Inah di Lembaga Keuangan Syariah: Tinjauan Konsep, Hukum dan Implementasi
}

\author{
Richa Angkita Mulyawisdawati \& Mufti Afif \\ STEBI Al-Muhsin Yogyakarta, Krapyak Wetan, Yogyakarta; \\ Universitas Darussalam Gontor, Sambirejo, Ngawi. \\ E-mail: $\underline{\text { mufti@gmail.com }}$
}

\begin{abstract}
The sale and purchase of 'inah and tawarruq is a classic problem that is recognized or not continues to grow and be practiced by individuals and financial institutions to date. Based on the facts on the ground, this type of engineering of sale and purchase occurs in Islamic Financial Institutions (LKS), where Islamic Financial Institutions only serve and serve financial services for its customers who need funds. So much is found that most LKS activities lead to financing through murabahah scheme where the scheme of the contract is considered safe for the LKS because the level of risk is lower than other types of contract. This paper is intended to determine the nature of the concept and legal sale and purchase 'inah and tawarruq according to scholars fiqh classics and how the practices of these two transactions became an issue on financial transactions in LKS. By using descriptive qualitative method, literature approach and history, it is produced that the type of sale of 'Inah and Tawarruq is still debated by the jurists of fiqh jurisprudence and the tendency is forbidden because there is a rift of ribawi transaction in it. While in practice in LKS is still widely applied and growing especially in superior products (murabahah) as in financing business capital, credit card, home financing or home renovation or the like and goldbased financing.
\end{abstract}

Keywords: bay 'Inah, Islamic Finance, Sharia Law.

\section{Pendahuluan}

Masalah jual beli inah adalah masalah klasik yang -secara tidak sengajaterus berkembang hingga saat ini. Di mana jual beli 'inah ini merupakan hillah (rekayasa) perdagangan yang bertujuan untuk meraup keuntungan semata. Rasulullah Saw melarang jual beli inah karena terdapat unsur riba yang merugikan pihak lain. sebagaimana Rasulullah Saw bersabda: 
"Apabila kalian telah berjual beli dengan cara Al-'Inah dan kalian telah ridha dengan perkebunan dan kalian telah mengambil ekorekor sapi dan kalian meninggalkan jihad, maka Allah akan menimpakan kepada kalian suatu kehinaan yang (Allah) tidak akan mencabutnya sampai kalian kembali kepada agama kalian". (HR. Abu Daud).

Hadist di atas mengisyaratkan bahwa Rasulullah Saw melarang jual beli 'inah, diungkapkan oleh beliau bahwa akibat bagi pelaku jual beli 'inah ini adalah kehinaan yang tidak pernah dilepaskan oleh Allah Swt.Diantara cara jual beli 'inah yang populer di dalam tulisan para ahli fikih adalah seseorang menjual suatu barang yang pembayarannya (ditangguhkan), lalu penjual tersebut segera membelinya (barang tadi) secara tunai dengan harga yang lebih rendah (dari yang ditawarkan). Lebih jelasnya bisa diilustrasikan berikut:Misalnya; bapak A menjual sebuah mobil kepada ibu B seharga 100 juta rupiah secara tangguh (kredit), yang berarti mobil langsung diserahkan kepada ibu B (pada waktu terjadi akad) sedangkan uang akan diserahkan pada enam bulan mendatang, kemudian di waktu yang sama bapak A membeli kembali mobil tersebut dari ibu B seharga 80 juta rupiah dibayar secara tunai, yang berarti mobil tadi kembali kepemilikannya kepada bapak A. Sedangkan ibu B memperoleh uang tunai saat ini sejumlah 80 juta rupiah, tetapi masih mempunyai kewajiban membayar hutang pada bapak $\mathbf{A}$ sejumlah 100 juta pada enam bulan mendatang. Bentuk akad seperti ini dikenal oleh kalangan ahli fikih sebagai jual beli 'inah.

Hakikatnya akad ini tidaklah dianggap sebagai transaksi jual beli, melainkan hanya sekedar pinjaman riba yang disamarkan dalam bentuk jual beli dan termasuk bentuk hilah (tipu daya/rekayasa) orang-orang yang senang melakukan riba. Sebagaimana dapat dilihat pada ilutrasi di atas tadi, bahwa bapak A mendapatkan keuntungan 20 juta rupiah dari jasa pemberian pinjaman uang kepada ibu $\mathbf{B}$ (yaitu sejumlah 80 juta). ${ }^{1}$ Benda mobil hanyalah sebagai perantara transaksi pinjam-meminjam uang supaya transaksinya dihukumi jual beli, yang disahkan oleh Islam.Berdasarkan fakta di lapangan, bentuk rekayasa jual beli 'inah kontemporer banyak terjadi di perbankan syariah, dimana Lembaga Keuangan Islam hanya menyajikan dan melayani jasa keuangan untuk nasabahnya yang membutuhkan. Didapatkan di lapangan bahwa kebanyakan kegiatan Lembaga KeuanganIslam mengarah pada pembiayaan melalui skema murabahah dan dengan pemesanan. Akad murabahah ini dianggap aman bagi pihak LKS karena tingkat risiko yang rendah dibandingkan jenis akad lain. ${ }^{2}$

Produk utama dari LKS seharusnya adalah lost and profit sharing yang terdiri dari musyarakah dan mudharabah, namun fakta yang terjadi adalah skim

1 Muhammad Shalah, Problematika Investasi Pada Bank Islam dan Solusi Ekonomi Islam, (terj), (Jakarta: Migunani, 1990), hal. 277.

2 Syafi'i Antonio, Bank Syariah; Analisis Kekuatan, Peluang, Kelemahan Dan Ancaman, (Yogyakarta, Ekonisia, 2002). 
murabahah menjadi produk utama pada LKS secara khusus perbankan Islam baik di Indonesia maupun Malaysia. Sehingga perlu disoroti tentang bagaimana aplikasi dan kedudukan dhoman (jaminan) dalam pembiayaan murabahah dimana jaminan diterapkan sebagai suatu keharusan yang wajib diberikan pihak nasabah ke LKS yang pada akhirnya menimbulkan adagium "tidak ada jaminan, maka tidak ada pembiayaan". ${ }^{3}$

Dari penjelasan diatas, nampak bahwa aplikasi baik bai al- inah pada produk LKS masih menjadi isu perdebatan para ulama, meskipun di Malaysia sendiri aplikasi prinsip tawarruq lebih dianjurkan dari pada bai al-inah. tetap Secara mendasar tetap saja masalah penerapannya kedua akad tersebut perlu disoroti lebih dalam dan tegas, agar dapat terlepas dari celah ribawi yang masih saja sering ditemukan khususnya di LKS Indonesia.Berkaca dari negara Malaysia, penulis ingin mengkaji lebih dalam mengenai konsep dan hukum kedua akad jual beli tersebut serta aplikasinya di lembaga keuangan Syari'ah di Indonesia.Berdasarkan uraian latar belakang di atas penulis akan mengkaji tentang konsep dan hukum bai'al- 'inahdan bai' tawarruqmenurut pendapat ulama fiqih klasik. Serta produkproduk yang mengandung unsur akad bai' al- 'inah pada LKS Indonesia.

\section{Jual Beli Model 'Inah; Definisi dan Implementasi}

Secara bahasa al- inah berarti pinjaman, dan dalam kamus disebut; 'ayyana berarti melakukan 'inah atau hutang, yaitu dengan cara; pedagang menjual barang dengan harga tangguh, lalu membelinya dengan bayar tunai dengan harga yang lebih rendah. ${ }^{4}$ Menurut terminologi ilmu fikih, 'inah artinya jual beli manipulatif untuk digunakan alasan peminjaman uang yang dibayar lebih dari jumlahnya. Yakni dengan cara menjual barang dengan pem-bayaran tertunda, lalu membelinya kembali secara kontan dengan harga lebih murah. ${ }^{5} \mathrm{Jual}$ beli 'Inah (Bai' Inah) merupakan praktik jual beli yang dilakukan oleh seorang penjual sedangkan inah merupakan sebuah penjualan dimana seorang pembeli membeli barang dari seorang penjual dengan harga yang telah ditentukan secara kredit dan kemudian barang tersebut dijual kembali oleh si pembeli kepada penjual aslinya dengan harga yang lebih rendah dari pada harga beli sebelumnya. ${ }^{6}$ Dari penjelasan diatas dapat dipahami bahwa sebetulnya motif pembeli adalah mendapatkan uang tunai namun mempergunakan barang sebagai perantara untuk mendapatkan uang tunai tersebut.

Sebagaimana ilustrasi di atas (lihat latar belakang): bapak A melakukan 'ain, yaitu ia bukan menginginkan menjual barang, tetapi yang diinginkannya adalah

\footnotetext{
${ }^{3}$ http://lib.law.ugm.ac.id/?p=632, Aspek Hukum Pembiayaan Murabahah Pada Perbankan Syariah, diakses pada tanggal 16 Agustus 2017 pukul 19.00

${ }^{4}$ Al-Fairuz Abadi, al-Qamus al-Muhith, (Damaskus), 254

5 http://pengusahamuslim.com/hukum-jual-beli-jual-beli-yang-diperdebatkan diakses pada tanggal 15 Agustus 2017 pukul 21.00

${ }^{6}$ Ayub, Al-Mu'amalat Al-Maliyah fil Islam, (Cairo: Dar El-Salam, 2002), hal. 110.
} 
'ain (yaitu uang). Atau karena si bapak A kembali memiliki 'ain (benda) yang dia jual.Ilustrasi lain; seseorang hanya mampu membayar uang muka sebesar 20 juta atas harga rumah yang ia butuhkan (senilai 100 juta rupiah) dari perusahaan properti,kemudian ia mendatangi Lembaga Keuangan Syariah (LKS) untuk memenuhi hajatnya -melunasi kekurangan pembayaran rumah- dan kemudian mengangsur ke LKS dengan akad murabahah. Mekanisme praktik ini masih dianggap sebagai akad murabahah yang disahkan oleh syariat Islam atau transaksi yang ditetapkan oleh fatwa DSN No. 04/ DSN-MUI/IV/2000 tentang murabahah oleh beberapa LKS di Indonesia. Padahal inilah jenis praktik yang termasuk dalam jual beli cara 'inah. Karena hakikatnya nasabah pinjam uang dari LKS yang tujuannya adalah melunasi sisa hutang yang belum terbayarkan pada perusahaan properti.

Ibnu Abidin mencontohkan mekanisme lain; bapak A (pemilik uang) menjual barangnya kepada ibu B (yang memerlukan uang) 12 juta dibayar secara tangguh. Lalu mereka melakukan serah terima barang, kemudianibu $\mathbf{B}$ menjualnya kembali ke ibu C (teman sekongkol bapak A) 10 juta dibayar tunai. Lalu ibu C menjual kembali ke bapak A seharga 10 juta secara tunai. Pada hakikatnya ibu B memerlukan dana sebesar 10 juta dan kemudian datang ke bapak $\mathbf{A}$ untuk meminjam dana tersebut. Sedangkan pihak bapak A tidak menyetujui akad pinjaman karena tidak menguntungkan bagi dirinya, maka bapak $\mathbf{A}$ berkata kepada ibu B: Saya akan menjual barang ini kepada anda seharga 12 juta secara tangguh jika anda setuju. Sedangkan harga dipasar berkisar 10 juta, silahkan anda menjualnya di pasar seharga 10 juta ke ibu C. Dalam contoh kasus ini pihak ibu Cmenyetujuinya dan menjual kembali barang tersebut ke bapak A dibayar secara tunai. Pada dasarnya peminjam atau ibu $\mathbf{B}$ hanya butuh dana, tetapi dipaksa untuk berjual beli. Bagaimana kelihaian ia berdagang dapat menghasilkan keuntungan lebih ataupun kurang.Ini berarti peminjam mendapat 10 juta tunai, pemberi pinjaman mendapat 12 juta secara tangguh. Hal ini berarti pemberian pinjaman dengan tambahan nilai, karena komoditi itu kembali pada penjualnya. Dan akad ini dapat berlaku untuk 2 orang atau tiga orang.

\section{Pendapat Ulama' Fikih tentang Jual Beli Model 'Inah}

Diriwayatkan dari Ibnu Abbas tentang seseorang yang menjual kain sutra kepada seseorang, lalu beliau tidak suka jika ia membelinya kembali dengan harga lebih rendah dari penjualnya. ${ }^{7}$ Kedua pelaku transaksi yang terjadi pada jual beli inah bertujuan untuk memperoleh hasil riba secara jelas, hanya saja mereka menjadikan akad jual beli sebagai penghalalan untuk suatu perbuatan yang haram. Sebagaimana diketahui perbuatan ini tidak akan menghapus keharaman riba dan tidak akan dapat menolak keburukan sebagaimana keburukan yang diakibatkan

7 Muhammad Shalah, Problematika Investasi Pada Bank Islam dan Solusi Ekonomi Islam, (terj), (Jakarta: Migunani, 1990), hal. 279 
oleh riba, bahkan bisa lebih buruk dari riba sendiri, karena pelaku 'inah berani menuntut hasil riba pada pihak terhutang secara hukum, sedang pelaku riba biasa tidak akan berani melakukan tuntutan seperti ini karena ia yakin bahwa perbuatan ini secara formalitas tidak diperbolehkan. Tujuan yang mencurigakan seperti ini tidak boleh dilalaikan karena Nabi SAW bersabda: "Suatu perbuatan diukur sesuai dengan niat (pelakunya), dan sesungguhnya semua orang akan memperoleh apa yang diniatkan". 8 Ibnu Qudamah juga berkata: "Barangsiapa yang menjual suatu komoditi secara tangguh, lalu ia membelinya kembali dengan harga yang lebih rendah secara tunai, maka perbuatan ini tidak diperbolehkan." Larangan ini diriwayatkan dari Ibnu 'Abbas, 'Aisyah, al-Hasan, Ibnu Sirin, asySya'by, an-Nakha'i, ats-Tsaury, al-Auza'i, Malik, Ishaq, dan Ashhab ar-Raiyi. ${ }^{9}$ Asy-Syaukani berkata: "Ulama yang menyatakan tentang tidak bolehnya jual beli 'inah adalah Malik, Abu Hanifah, Ahmad dan al-Hadiwiyah." 10

Adapun alasan ulama tersebut adalah sebab jual beli 'inah merupakan sebuah bentuk transaksi yang di dalamnya terdapat unsur riba dan manipulasi. ${ }^{11}$ Membahas mengenai jual beli 'inah ini, akan lebih menarik ketika mengkaji pendapat Ibn Taimiyah. Menurut Ibn Taimiyah jual beli dibagi menjadi tiga jenis, antara lain; (1) Seseorang membeli barang dengan tujuan mengkonsumsinya, dan ini hukumnya adalah halal (2) Seseorang yang membeli barang untuk dijual kembali, dan hal ini hukumnya pun halal karena tidak ada larangan terhadap jual beli (bisnis), (3) Seseorang membeli barang bukan untuk tujuan konsumsi dan bisnis, tetapi untuk tujuan mendapatkan cash money. Karena dalam mendapatkan cashmoneytersebut sangatlah sulit, sehingga seseorang tersebut membeli barang dengan harga yang tinggi dan kemudian menjualnya kembali kepada penjual semula dengan harga yang lebih rendah untuk mendapatkan uang tunai. ${ }^{12}$ Menurut suatu riwayat yang lain, Imam Syafi'i memperbolehkan jual beli inah sesuai dengan sabda Rasulullah SAW: "Tukarlah biji-bijian kualitas buruk dengan uang, dan dengan uang tersebut belilah bijibijian kualitas baik". ${ }^{13}$

Hassan Ahmed sebagai manajer direktur Dayax Islamic Bank menyatakan bahwa Bai' Inah dapat diaplikasikan didalam praktik perbankan dengan beberapa ketentuan sebagai berikut ${ }^{14}$ :

${ }^{8}$ Ibid, hal 279.

${ }^{9}$ Ibnu Qudamah, al-Mughni, jilid IV, (Dar-Alam Kutub: Riyadh), hal. 45.

${ }^{10}$ Asy-Syaukani, Nail al-Authar, Jilid III, (Dar-Hadis, Kairo, Mesir), hal. 207

${ }^{11}$ Asy-Syafi'i, Al-Umm, (Dar Al-Kutub Publishing: Beirut,1993), hal. 301

12 Muhamad Nadratuzzaman Hosen, Amirah Ahmad Nahrawi, "Comperative Analysis of Islamic Banking Products between Malaysia and Indonesia”, International Journal of Academic Research in Economics Sciences, April 2012, Vol. 1, No 2, 2012, hal. 126.

${ }^{13}$ Nahrawi, Al-Imam Asy Syafi 'i fi Madzhabihi Al-Qadim Wa Al-Jadid, (Jakarta: Yayasan AnNahrawi, 1994), 103.

${ }^{14}$ Hasan O. Ahmad, "Shariah Contracts in Islamic Banking and Finance”, a Presentation by Managing Director of Dayax Islamic Bank, hal. 40. 
1) Haruslah terdapat dua akad yang berbeda. Akad yang pertama yaitu akad penjualan oleh Bank kepada nasabah dengan pembayaran secara tangguh. Sedangkan akad yang kedua yaitu akad pembelian oleh Bank dari nasabah dengan pembayaran secara tunai.

2) Adapun aset jual beli 'Inah bukan merupakan aset ribawi yang dijadikan media pertukaran (emas, perak atau mata uang) sebab seluruh pembayaran untuk kegiatan jual beli haruslah menggunakan uang tunai.

3) Setiap akad mengandung unsur atau elemen yang penting, dan masingmasing elemen harus memenuhi syarat yang telah ditetapkan.

\section{Implementasi Jual Beli Model 'Inah di Lembaga Keuangan Syariah}

\subsection{Pembiayaan Modal Kerja}

Bagya dalam penelitiannya tentang praktik murabahah di Bank Syari'ah Indonesia dan Malaysia menemukan bahwa Malaysia mempraktikkan salah satu skema pembiayaan yang dikemas dalam produk murabahah yaitu pembiayaan modal kerja dimana hal tersebut dikategorikan sebagai praktik kecurangan dalam perdagangan. ${ }^{15}$ Dalam pembiayaan ini terdapat kecurangan pada dua kesepakatan, yaitu ketika si peminjam ingin meminjam sejumlah uang, padahal disisi lain dalam Islam tidak ada hutang piutang yang didalamnya mengandung bunga, sedangkan bai' Inah disepakati oleh sebagian besar ulama bahwa jual beli Inah diperbolehkan hanya jika tidak terdapat unsur bunga atau riba didalamnya. Misalnya, terdapat sebuah transaksi dimana A membutuhkan sejumlah uang tunai sebesar Rp 10 juta untuk pengembangan bisnisnya. Kemudian dia datang ke LKS untuk mengajukan pembiayaan tersebut lalu pihak LSK menyetujui pengajuan pembiayaan tersebut dengan menjual aset kepada A senilai Rp 10 Juta dengan menggunakan skema pembayaran tangguh. Kemudian pembeli yaitu pihak A akan membuat kesepakatan baru dengan bank syari'ah untuk menjual kembali aset yang dibelinya dari bank syari'ah tersebut secara tunai senilai Rp. 8 Juta. Pada kasus ini, dapat dipahami bahwa kedua belah pihak yaitu pihak A dan bank syari'ah sama-sama mendapatkan keuntungan dimana pihak A mendapat pinjaman sebesar Rp 10 Juta dan LKS akan mendapatkan keuntunguan (profit) sebesar Rp 2 Juta (didapatkan dari Rp 10 Juta - Rp 8 Juta).

Menurut Al-Amin Ahmad dalam penelitian yang dilakukan oleh Prabowo berpendapat bahwa transaksi seperti ilustrasi diatas merupakan transaksi yang dapat dikategorikan ke dalam transaksi makruh (lebih baik dihindari, namun jika dilakukan tidak termasuk dosa) dengan alasan bahwa tidak ada keterpaksaan atau tekanan sebab pembeli pada dasarnya tidak membutuhkan barang atau aset yang dijadikan objek transaksi jual beli akan tetapi pembeli hanyalah membutuhkan uang. Sementara pihak penjual yaitu LKS tidak akan dengan mudah memberikan pembiayaan kecuali pada akad yang telah dilakukan sebelumnya. Pembiayaan modal kerja juga diaplikasikan di LKS di Indonesia,yaitu pembiayaan modal kerja untuk pembelian perlengkapan pabrik atau perusahaan. Dimana LKS akan membeli barang-barang dari supplier yang kemudian akan dijual kepada pembeli

15 Bagya Agung Prabowo, 2008, "The Practice of Murabahah Scheme in Syariah Banking (Critical Analysis Towards The Aplication of Murabahah Scheme in Indonesia and Malaysia)", Bagya@fh.uii.ac.id 
dengan harga yang sama dan sejumlah keuntungan untuk LKS sesuai dengan kesepakatan antara kedua belah pihak. Namun secara praktik, LKS menggunakan skema murabahah bil wakalah, yang berarti LKS hanya menyerahkan sejumlah dana yang dibutuhkan oleh pembeli barang/ perlengkapan usahanya (nasabah) dan selanjutnya pihak nasabah melaporkan hasil pembeliannya tersebut dengan janji akan membayar lebih besar dari yang ia terima tadi sesuai dengan kesepakatan di awal.

\subsection{Kartu Kredit Syari'ah}

Mas'um Billah memaparkan dalam tulisannya, bahwa konsep kartu kredit diperbolehkan dalam konsep syari'ah, jika di dalamnya tidak mengandung unsur ribawi. ${ }^{16}$ Di Malaysia, kartu kredit syari'ah pertama kali dikembangkan oleh AmBank pada bulan Desember 2001. Bank ini meluncurkan Al-Tsaqif Credit Card yang menggunakan akad ba'i inah dengan margin keuntungan sebesar $1.25 \%$ per bulan atau $15 \%$ per tahun dari seluruh total pembelian. Di dalam konsep Bai' 'inah terdapat dua kontrak terpisah, yaitu bai' al-Mutlaq (penjualan secara tunai) dan yang kedua adalah bai' bithaman ajil (penjualan dengan termin pembayaran) dimana keduanya berlangsung setelah satu akad selesai. Pada transaksi awal, pihak bank (LKS) menyetujui untuk menjual barang atau aset tertentu kepada pemegang kartu kredit dengan harga tertentu. Kemudian pada transaksi kedua, pihak pemegang kartu kredit menyetujui untuk menjual kembali barang atau aset yang telah dibelinya dari bank (LKS) dengan harga yang lebih rendah. ${ }^{17}$ Untuk lebih jelasnya, mekanisme penggunaan kartu kredit syari'ah di Malaysia adalah sebagai berikut: ${ }^{18}$

\footnotetext{
16 Profesor di Islamic Financial Regulations, King Abdul Aziz University, Jeddah. Profesordi Islamic Financial Applications, University of Camden, USA. Assoc. Professor of Law (Insurance, Takaful, Islamic Banking, Finance \& E-Commerce), Faculty of Economics and Management Sciences, International Islamic University Malaysia. Beliau juga seorang konsultan pada beberapaperusahaan dan institusi (lokal dan internasional) bidang asuransi, Perbankan, Keuangan dan teknologi Informatika, Manajemen aset dan kekayaan, Pasar Modal Islam, Dinar dan lainlainbaik dalam disiplin ilmu modern maupun syari'ah. Juga penulis lamanhttp//.www.islamicinsurance.com. E-mail: masum2001@yahoo.com

17 Ibid

${ }^{18}$ Mohd Ma'sum Billah, Modern Financial Transaction Under Shariah, hal. 48-49.
} 


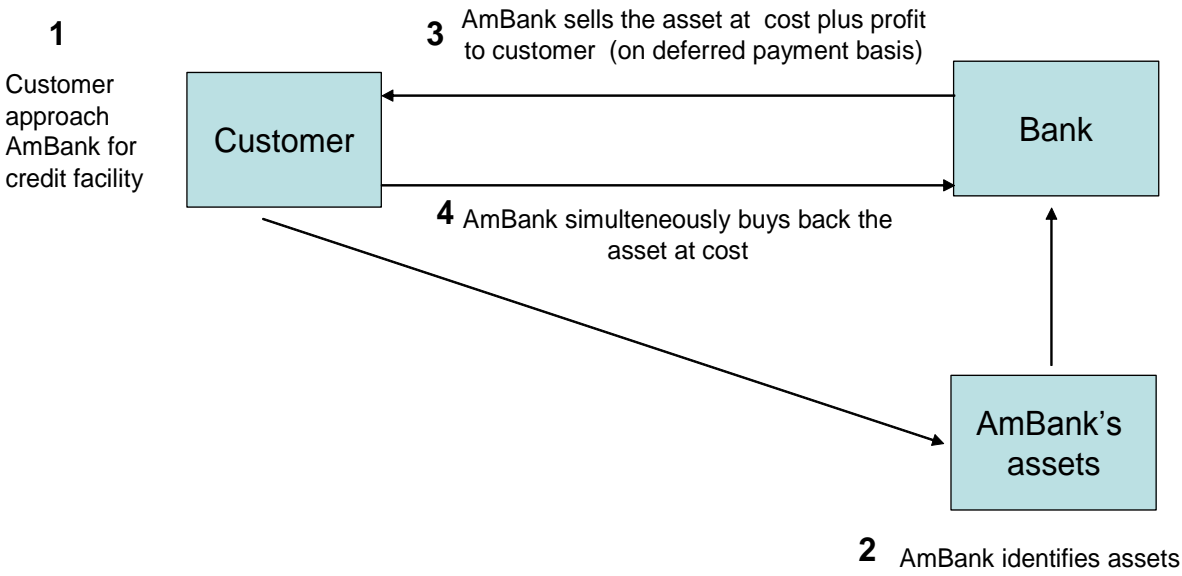

Penjelasan dari gambar di atas adalah, di mana nasabah yang ingin menggunakan layanan kartu kredit akan mendatangi AmBank Berhard atau AmFinance Berhard. Pihak bank akan menyiapkan formulir dan aplikasi yang akan diproses setelahnya. Jika formulir dan persyaratan sudah dilengkapi oleh nasabah, kemudian akan terdapat proses jua beli 'inah. Pihak Ambank akan mengidentifikasi aset yang dimilikinya apakah aset kolektif atau perorangan, dimana nilai jual aset sebanding atau senilai dengan fasilitas kredit yang akan digunakan. Contohnya, jika fasilitas kredit senilai $10.000 \mathrm{RM}$ maka nilai jual aset harus seharga 10.000 RM juga. Hal ini akan sesuai dengan kriteria aset yang diperjual belikan dalam konteks syari'ah, diantaranya adalah:

a) Aset atau barang yang diperjual-belikan tersedia ketika akad berlangsung. Pengecualian untuk akad Salam, Istishna', Jualah dan Ijarah.

b) Aset atau barang yang diperjual belikan adalah milik sendiri (Milik Bank).

c) Aset atau barang yang diperjual belikan memiliki manfaat baik bagi penjual maupun pembeli.

d) Aset atau barang yang diperjual belikan mempunyai nilai jual.

Kemudian, AmBank akan menjual barang atau aset yang telah diidentifikasi tadi kepada nasabah. Harga jual merupakan jumlah total dari biaya dan profit atau keuntungan (biasanya dalam bentuk prosentase). Lalu akad selanjutnya adalah ketika pihak AmBank membeli kembali aset yang dijual tadi dari nasabah secara tunai. Nasabah kemudian menggunakan uang tunai ini untuk membeli barang dan jasa menggunakan layanan kartu kredit yang telah disediakan.

Mengapa transaksi semacam ini tidak termasuk dalam kategori riba? Alasan yang diberikan oleh pihak AmBank adalah bahwa harga yang telah ditinggikan tersebut berdasarkan atas akad jual beli bukan pinjaman. Dan semua transaksi 
yang menggunakan aset atau barang sebagai medianya diperbolehkan oleh Syari'ah di Malaysia. Sehingga, pada teorinya kartu kredit syari'ah tidak berdasarkan pada pinjaman, akan tetapi lebih pada transaksi bisnis dan jasa, dimana pihak Bank menjual dan membeli kembali pada harga yang rendah untuk mendapatkan keuntungan.Fenomena tersebut terlihat sangat kontras dimana penggunaan kartu kredit itu sendiri tidak dapat diterima oleh para Ulama dari Timur Tengah dan Indonesia sebab hal tersebut dianggap sebagai transaksi palsu. Ditambah lagi dalam perkembangannya, pada bulan Juli 2002, Bank Islam Berhad (BIMB) juga meluncurkan produk yang sama yaitu kartu kredit syari'ah. Bank ini mengklaim bahwa produk kartu kredit mereka ini adalah kartu kredit syari'ah murni pertama. Kartu kredit yang diluncurkan oleh BIMB menggunakan tiga akad yang berbeda, diantaranya; ba'i innah, wadi'ah (deposito), dan qard hasan.

\subsection{Pembiayaan atau Renovasi Rumah}

Al Amin Ahmad dalam penelitian Prabowo juga menambahkan pada saat ini Bank Muamalat Malaysia Berhad (BMMB) masih menggunakan akad jual beli Innah. Berdasarkan data diatas tahun 2007 menunjukkan bahwa pembiayaan rumah mencapai 70-80\% dari total pembiayaan di BMMB yaitu sekitar lebih dari 5.6 Milyar Ringgit Malaysia (RM). Secara konsep, produk pembiayaan rumah yang ditawarkan oleh pihak BMMB menggunakan akad Ba'i Bitsamanil Ajil (BBA). Akad tersebut merupakan akad murabahah (jual beli) rumah dengan pembayaran tertunda. Namun demikian, seluruh perbankan syari'ah di Malaysia termasuk BMMB dianggap kurang tepat mengaplikasikan akad tersebut. Sebab, akad BBA pada dasarnya sama dengan konsep akad $B a$ ' $i$ 'inah.

Konsep yang serupa juga terdapat di dalam produk pembiayaan perbankan syari'ah di Indonesia. Yaitu pembiayaan untuk renovasi rumah, dimana pembeli mengajukan pembiayaan untuk renovasi rumah kepada bank syari'ah yang kemudian pihak bank akan memberikan dana. Pembeli akan mendapatkan surat kuasa, yang fungsinya adalah sebagai hak untuk membeli barang-barang material yang diperlukan untuk renovasi rumah. Kemudian bank akan memberikan waktu selama 30 hari (1 bulan) kepada pembeli untuk membeli barang-barang dengan bukti pembelian berupa nota tagihan atau invoice. Praktik tersebut diaplikasikan sebab bank sebagai penjual ( $\left.b a^{\prime} i\right)$ mengalami kesulitan untuk membeli barangbarang material yang diperlukan untuk merenovasi rumah nasabah. ${ }^{19}$ Contoh lainnya adalah akad pembiayaan murabahah untuk pembelian rumah (Kredit Pembelian Rumah (KPR) oleh BTN Syari'ah). Pertama tama, pihak bank akan membeli rumah untuk nasabah (yaitu pihak pembeli) dari pihak pengembang (developer) kemudian bank akan menjual rumah tersebut kepada nasabah

19 Muhammad Shalah, Problematika Investasi Pada Bank Islam dan Solusi Ekonomi Islam, (terj), (Jakarta: Migunani, 1990), hal. 279. 
(pembeli) dengan harga yang sama ditambah dengan sejumlah profit yang disetujui oleh kedua belah pihak yaitu pihak bank dan nasabah.

\subsection{Pembiayaan Berbasis Emas}

Praktik lain dari akad bai' al-inah yang penulis temukan di lapangan adalah pembiayaan berbasis emas. Hal tersebut penulis temukan di salah satu BMT di Yogyakarta dimana terdapat seorang nasabah yang mengajukan pembiayaan untuk pembayaran down payment sebuah mobil. Kemudian nasabah tersebut ditawari oleh pihak BMT untuk membeli emas kepada BMT dengan akad murabahah. Setelah nasabah membeli emas dari BMT dengan pembayaran secara termin, maka nasabah boleh menjual kembali kepada BMT tersebut atau kepada pihak lain secara tunai dengan harga yang lebih rendah tentunya. ${ }^{20}$ Kasus tersebut menurut hemat penulis termasuk dalam praktik jual beli inah dimana pihak BMT yang bersangkutan telah menawarkan emas yang telah dibeli oleh nasabah dengan skema murabahah dan pembayaran secara termin lalu dijual kembali kepada BMT tersebut atau pihak lain. Adapun tujuan menjualnya kembali adalah untuk mendapatkan uang tunai yang dapat digunakan untuk membayar down payment pembelian sebuah mobil.

\section{Kesimpulan}

Berdasarkan pada pembahasan di atas dapat menarik beberapa kesimpulan berikut; pertama, jual beli 'Inah (Bai' Inah) merupakan praktik jual beli yang dilakukan oleh seorang penjual sedangkan 'Inah merupakan sebuah penjualan dimana seorang pembeli membeli barang dari seorang penjual dengan harga yang telah ditentukan secara kredit dan kemudian barang tersebut dijual kembali oleh si pembeli kepada penjual aslinya dengan harga yang lebih rendah dari pada harga beli sebelumnya. Adapun Ulama yang menyatakan tentang tidak bolehnya jual beli 'inah adalah Malik, Abu Hanifah, Ahmad dan al-Hadiwiyah. Alasan ulama tersebut adalah sebab jual beli 'inah merupakan sebuah bentuk transaksi yang di dalamnya terdapat unsur riba dan manipulasi. Sedangkan Imam Syafi'i memperbolehkan jual beli 'innah sesuai dengan sabda Rasulullah SAW: "Tukarlah biji-bijian kualitas buruk dengan uang, dan dengan uang tersebut belilah biji-bijian kualitas baik”. Produk-produk lembaga keuangan syari'ah yang di dalamnya mengandung unsur akad bai' al- 'inah antara lain; Pembiayaan Modal Kerja, Kartu Kredit Syari'ah, Pembiayaan atau Renovasi Rumah dan pembiayaan berbasis emas.

${ }^{20}$ Hasil wawancara dengan ibu Wira, calon nasabah dan praktisi di salah satu BMT di Yogyakarta pada tanggal 5 September 2017 pukul 14.30 WIB. 


\section{Daftar Pustaka}

Ahmad, Hasan O. "Shariah Contracts in Islamic Banking and Finance". A Presentation by Managing Director of Dayax Islamic Bank.

Al-Fayruz 'Abadi, 1411 H; Ibn Manzur 1990; al-Lughawi, 1986, al-Qamus alMuhith, Jilid 4, Damaskus.

Asy-Syafi'i. 1993. Al-Umm. Beirut. Dar Al-Kutub Publishing.

Asy-Syaukani. Nail al-Authar. Jilid III. Dar-Hadist.Kairo. Mesir.

Ayub, H. 2002. Al-Mu'amalat Al-Maliyah fil Islam. Cairo. Dar El-Salam.

Billah, Mohd Ma'sum. Modern Financial Transaction under Shariah.

Hosen, Muhamad Nadratuzzaman \& Nahrawi Amirah Ahmad. "Comperative Analysis of Islamic Banking Products between Malaysia and Indonesia”, International Journal of Academic Research in Economics Sciences April 2012, Vol. 1, No 2.

Qudamah, Ibnu. al-Mughni. jilid IV. Dar-Alam Kutub. Riyadh.

Kamal, Abu Malik. 2011. Shahih Fiqh - as Sunnah, Jilid 4. Jakarta. Pustaka Azzam.

Nahrawi A S. 1994. Al-Imam Asy Syafi'i fi Madzhabihi Al-Qadim Wa Al-Jadid. Jakarta. Yayasan An-Nahrawi.

Prabowo, Bagya Agung. 2008. "The Practice of Murabahah Scheme in Syariah Banking (Critical Analysis Towards The Aplication of Murabahah Scheme in Indonesia and Malaysia)". Bagya@fh.uii.ac.id

Shalah, Muhammad. 1990. Problematika Investasi Pada Bank Islam dan Solusi Ekonomi Islam. (terj). Jakarta. Migunani.

Syafi'I, Antonio. 2002. Bank Syariah; Analisis Kekuatan, Peluang, Kelemahan dan Ancaman. Yogyakarta, Ekonisia.

http://lib.law.ugm.ac.id/?p=632, Aspek Hukum Pembiayaan Murabahah Pada Perbankan Syariah, diakses pada tanggal 16 Agustus 2017 pukul 19.00

http://pengusahamuslim.com/hukum-jual-beli-jual-beli-yang-diperdebatkan diakses pada tanggal 15 Agustus 2017 pukul 21.00 